\title{
MULTIPLE-CRITERIA MODEL FOR OPTIMAL OFF-ROAD VEHICLE SELECTION FOR PASSENGER TRANSPORTATION: BWM-COPRAS MODEL
}

\author{
Dragan S. Pamučar ${ }^{a}$, Lazar M. Savin ${ }^{b}$ \\ University of Defence in Belgrade, Military Academy, \\ Department of Logistics, Belgrade, Republic of Serbia, \\ a e-mail: dragan.pamucar@va.mod.gov.rs, corresponding author, \\ ORCID iD: (i)http://orcid.org/0000-0001-8522-1942 \\ b e-mail: lazarsavin96@gmail.com, \\ ORCID iD: (1)http://orcid.org/0000-0002-6121-936X
}

DOI: 10.5937/vojtehg68-22916; https://doi.org/10.5937/vojtehg68-22916

\begin{abstract}
FIELD: Mathematics, Transport, Logistics ARTICLE TYPE: Original scientific paper ARTICLE LANGUAGE: English
\end{abstract}

\begin{abstract}
:
Introduction/purpose: Adequate evaluation and choice of off-road vehicles used in performing various types of assignments is a very important factor which affects user mobility and safety as well as the quality and efficiency of carrying out transportation activities in the Serbian Armed Forces (SAF).

Methods: This paper thus proposes the BWM (Best Worst Method) and the COPRAS (Compressed Proportional Assessment) models for the selection of the optimal off-road vehicle for the needs of the SAF. The relative weight of the criteria used to assess potential off-road vehicles was established using the BWM method. In addition to the COPRAS method which is a component of the basic decision-making model, in this paper, the MABAC (MiltiAttributive Border Approximation Area Comparison) and MAIRCA (MultiAttributive Ideal-Real Comparative Analysis) methods were also applied through result validation.

Results: By testing the BWM-COPRAS model on the example of optimal off-road vehicle selection in the SAF, a high rank correlation was achieved. The results were validated through the statistical processing of the results obtained through the implementation of various multi-criteria techniques by applying the Spearman's rank correlation coefficient.

Conclusion: The results display stability of the results of the proposed model in ranking alternatives and prove the feasibility of the proposed approach to handle multi-criteria decision making problems.
\end{abstract}

Key words: BWM, COPRAS, MABAC, MAIRCA, vehicle selection, multi-criteria decision making. 


\section{Introduction}

When observing the efficiency of units in off-road conditions in both peace and war, it is impossible to miss its high dependence on adequate vehicle selection for carrying out a mission, for it is precisely this process that represents an important factor which directly influences the lowering of risk and time involved in performing this activity. Proper assessment and selection of the right vehicle provides proper conditions for efficient performance of tasks set before the units of the Serbian Armed Forces (SAF). Taking into consideration the aforementioned, the optimal off-road vehicle selection process is of great importance for successful and safe transport of units. Identifying actions that have the biggest impact on the efficiency of vehicles during task performance enables the users (units) to modify the operation accordingly and reduce the time needed to perform these activities. This research paper presents the multi-criteria BWM-COPRAS model for evaluation and optimal off-road vehicle selection for the units of the Serbian Armed Forces. The hybrid BWMCOPRAS model is carried out in three phases. The first phase of the model includes calculating the optimal values of weight coefficients by applying the non-linear model in BWM. The second phase is where the COPRAS model is applied. The values put into the COPRAS model represent the values of the BWM weight coefficients, and the elements of the basic Decision matrix. The third phase includes the validation of the obtained results through: (1) the comparison of the results with other multi-criteria (MCDM) models, (2) the analysis of the result stability in a dynamic environment, and (3) the analysis of the result stability when the weight coefficients of the criteria are changed.

Through research and development of the models, several goals have been set in this paper. The first goal pertains to the advancement and enhancement of the optimal vehicle selection methodology in the area of multi-criteria decision making through development and introduction of a new FUCOM-COPRAS approach. The second goal of this paper is to bridge the gap that currently exists in the evaluation and adequate vehicle selection methodology within the military as a whole. The third goal of the paper is a possibility of enhancing the efficiency and lowering the risks of performing SAF assignments by defining models for adequate vehicle selection. And the fourth goal of this paper is the popularization and affirmation of the idea of multi-criteria decision making in reaching complex decisions in the SAF through a presentation of the BWM-COPRAS model. 
The authors of this paper have opted for the use of the hybrid BWMCOPRAS model due to its following advantages. (1) Use of the BWM and COPRAS models enables a successful simulation of the decision-making processes, starting from defining the goal, criteria and alternatives, to comparison of the criteria, i.e. establishing the priority of each of the alternatives over the set goal. (2) Application of the BWM-COPRAS model breaks down the concrete decision making process by taking apart the problem into a hierarchy of its elements. A hierarchical examination of the decision making process allows for easier control over the consistency of estimates while paying attention to the entirety of the problem and functional interactions between criteria and alternatives. (3) Using the BWM-COPRAS model enables the integration of the qualitative and quantitative factors into decision making, because most real problems most often occur as a combination of qualitative and quantitative elements. (4) The BWM-COPRAS model successfully identifies and points to the inconsistency of the decision-maker by tracking the inconsistencies of estimates during the entire process, and calculating the index and ratio of consistency. (5) Redundancy of pair comparison makes the BWM-COPRAS model less sensitive to estimation errors. (6) The implementation of the BWM-COPRAS model in group decision making significantly improves communication between group members. In case of a discussion, a group must agree on every joint estimate that is to be entered into the matrix. This helps in structuring the discussion and reaching a consensus.

The BWM-COPRAS model also has certain limitations which the users might encounter while using it, such as: (1) insufficiently large scale (Saaty scale of relative importance) for comparison of elements in pairs, related to some decision making problems; (2) the number of necessary pair comparisons which is not negligible in most problems; (3) frequent difficulty in achieving an acceptable consistency ratio; and (4) the complexity of the mathematical algorithm which can be a limiting factor for widespread use of the model.

This paper contains a total of six sections, the first of which refers to introducing the problem of adequate vehicle selection for the SAF. The second, containing the literature review, takes a closer look at the already existing research on similar topics in which multi-criteria decision making models were applied. The third section briefly introduces the previously used models and lays out the algorithm of the hybrid BWMCOPRAS model. The fourth section displays a study of the case in which vehicle evaluation was performed by using the BWM-COPRAS model. The fifth section is a discussion of the results which includes a result 
stability check through the change of the weight coefficients of the criteria in the BWM, and the validation of the obtained results through comparison with other MCDM models. The sixth section shows the key contributions of the developed model and the performed research, as well as suggestions for future research.

\section{Literature review}

Based on research from the most important indexes of international science journals (SCOPUS and Web of Science), a literature analysis has been performed which demonstrates the implementation of MCDM models in transport and logistics optimization. It analyzes the period between 2008 and 2018. During this period, only two papers on the topic of vehicle selection in the military were published (Pamučar, et al, 2013); (Starčević, et al, 2019). Starčević et al (2019) have presented the selection of military vehicles for use in multinational operations by using the hybrid AHP-DEA (Analytic Hierarchy Process - Data Envelopment Analysis) models, while Pamučar et al (2013) have shown the application of the neuro-fuzzy system for the selection of military motor vehicles used for performing transportation assignments in the SAF. Due to scarcity of papers on the topic of application of the MCDM models for military off-road vehicle selection, this paper analyzes papers from the domain of transport and logistics which deal with similar topics. For example, Jeon et al (2010) showed the application of the MCDM methods in the sustainable transport plan selection based on the sustainability index. In the research, the authors used the Weighted Sum Model. Cadena \& Magro (2015) presented a new methodology for assigning the weight coefficients of the sustainability criteria in transport projects. In order to solve the problem of imprecision and subjectivity, the authors applied the MCDM models in fuzzy environment.

Given that the traffic system is the life force of every country and one of the bases for its economic development, Baric et al (2016) suggest that the AHP method be applied when choosing the best project in the realization of city traffic projects. The model has been tested on a real system and has yielded reliable results. Barić et al (2016) have also pointed out the main drawback of applying the AHP model which is a large number of inputs making the validation of the obtained results more difficult. In order to solve this problem, Inti \& Tandon (2017) presented a modified AHP method characterized by additive transitivity of fuzzy relations. The model was tested in choosing a contractor for the construction of transportation infrastructure. 
In order to improve sustainability in transport, one of the solutions is to use various alternative fuels and vehicle propulsion systems. In this way, with the help of the sustainability index, Mitropoulos \& Prevedouros, (2016) make estimates of vehicle characteristics. The identified indicators were grouped into five categories of sustainability: Environment, Technology, Energy, Economy and Users, and then they were aggregated using the WSM method. Also, Safaei Mohamadabadi et al (2009) have selected the types of propulsion fuel for vehicles based on three basic sustainability aspects. For ranking the alternatives based on the five criteria, the PROMETHEE method was used. Intermodal transportation can greatly improve the sustainability of a transportation system. It is necessary to choose the optimal location of terminals based on different requirements of different partakers in a transportation process. With that aim, Zečević et al (2017) have suggested a new hybrid MCDM model for selecting locations. Sustainable transport systems have today become a necessity, especially in large cities because of various harmful effects on the environment. An approach for choosing the best alternative of transport systems based on 24 criteria grouped in three categories was defined in (Awasthi et al, 2011). The abovementioned approach contains three steps, and the TOPSIS method is applied in a combination with fuzzy theory with the aim to assess the criteria and choose an alternative. Castillo \& Pitfield (2010) suggest the Evaluative and Logical Approach to Sustainable Transport Indicator Compilation (ELASTIC) framework for choosing a sustainable transport system indicator with the help of AHP and SAW methods. Although the improvements of transport planning methods over the past few years are visible, according to López \& Monzón (2010), in order to improve the sustainability level in transport, it is necessary to apply a multidiciplinary approach based on GIS. In addition to that, it is necessary to integrate methods of multi-critearia decision making within the suggested approach.

An estimate of transport system sustainability in individual European countries based on selected economic, ecological and social indicators was presented in Bojković et al (2010). The ELECTRE (ELimination and Choice Expressing Reality) method was used together with its modification based on the Absolute Significance Treshold (AST). The framework for selecting sustainable transport projects in urban areas of developing countries was proposed in Jones et al (2013). The choice of alternatives is performed based on the Localized Sustainability Score index whereby the AHP method is used. In addition to the AHP method, assessing the sustainability of different transport solutions such as mode 
sharing, multimodal transport, intelligent transportation systems, Awasthi \& Chauhan (2011) use the Dempster-Shafer theory in the proposed hybrid approach. While the AHP method is primarily used for ranking criteria based on their weight, the Dempster-Shafer theory enables a synthesis of multiple information sources. Dimić et al (2016) have developed a model for strategic transport steering based on the SWOT analysis, fuzzy Delphi and DEMATEL - ANP method.

There are a certain number of studies which contemplate the application of different theories of uncertainty in multi-criteria models for solving numerous logistical and transportation problems. For example, Sremac et al (2018) have shown the ranking of logistical providers by using the Rough SWARA (Step-Wise Weight Assessment Ratio Analysis) and Rough WASPAS (Weighted Aggregated Sum Product Assessment) models, while Badi et al (2018) demonstrated the use of the CODAS model. Later, Badi \& Ballem (2018) and Stević et al (2017) demonstrated the application of rough numbers in multi-criteria models for vehicle rationalization within the inner transport of logistical companies. The paper puts forward a new approach based on the combination of the Simple Additive Weighing (SAW) method and the rough BWM. Radović et al (2018) showed the use of rough numbers for valuating performance indicators which was applied in three different countries: Bosnia and Herzegovina, Libya and Serbia. The multi-criteria model includes the use of the rough ARAS (Additive Ratio Assessment) approach for performance indicator valuation in nine transportation companies from the three countries. Pamučar et al (2019) have shown the possibilities of applying the multi-criteria models based on Linguistic Neutrosophic Numbers (LNN) in managing human resources in the process of transporting hazardous substances. The application of the LNN-WASPAS model for the evaluation of security advisors when transporting hazardous substances on Serbian soil was demonstrated. Pamučar et al (2016) showed a green $p$-median problem combined with a fuzzy multi-criteria model which processes environmental parameters, sociological parameters and the expenses of logistical distributors and applies their influence on the planning of the city logistical terminal location in a discrete traffic network.

Sustainability is a very important concept in logistics, and reverse logistics as one of its sub-branches can greatly improve the efficiency and the ecological aspect of doing business. Wang et al (2018) have presented a method for choosing returnable product collectors. The hybrid approach based on the AHP and Entropy Weight (AHP-EW) methods is used in order to estimate the weight of certain criteria, while 
the Multi-Attributive Border Approximation area Comparison (MABAC) method is used for ranking the alternatives. Different initiatives for city logistics (e.g. proper location of distribution centers) can significantly contribute to improving the degree of sustainability in a city. This is precisely the research topic in (Awasthi \& Chauhan, 2012). Out of the MCDM methods, the aforementioned paper uses the AHP and Fuzzy TOPSIS. With the help of the Fuzzy Step-wise Weight Assessment Ratio Analysis (SWARA) and Fuzzy MOORA, Mavi et al, (2017) perform a selection of a third-person provider of reverse logistics services in the plastic industry. Later, Badi and Ballem, (2018) showed the possibilities of applying the BWM and MAIRCA models for selecting a third-person provider for reverse logistics services in the pharmaceutical industry. Pamučar \& Ćirović, (2015) demonstrated the application of the hybrid DEMATEL-MABAC model in the process of making investment decisions about the acquisition of manipulative vehicles in logistics centers. The DEMATEL method was used for obtaining the weight coefficient of criteria, while the valuation and selection of forklifts was done by using the MABAC model. The following table (Table 1) shows an overview of fields which most frequently employ the MCDM models.

Table 1 - MCDM methods in the transport and logistics subfield Таблица 1 - МCDM методы в области транспорта и логистики Табела 1 - ВКО методе у области транспорта и логистике

\begin{tabular}{|c|c|c|}
\hline $\begin{array}{l}\text { Field of application for the MCDM } \\
\text { method }\end{array}$ & MCDM method & Literature \\
\hline $\begin{array}{l}\text { Determining the impacts of } \\
\text { ecological transport measures on } \\
\text { city sustainability }\end{array}$ & $\begin{array}{l}\text { AHP; AHP-EW; } \\
\text { MABAC; FUCOM }\end{array}$ & $\begin{array}{l}\text { (Awasthi et al, } \\
\text { 2011); (Zečević et } \\
\text { al, 2017); } \\
\text { (Fazlollahtabar et } \\
\text { al, 2019); } \\
\text { (Stanković et al, } \\
\text { 2019); (Nunić, } \\
\text { 2018) }\end{array}$ \\
\hline $\begin{array}{l}\text { Logistical provider assessment with } \\
\text { acknowledging the risks and } \\
\text { sustainability }\end{array}$ & $\begin{array}{l}\text { Fuzzy SWARA, Fuzzy } \\
\text { MOORA }\end{array}$ & (Mavi et al, 2017) \\
\hline $\begin{array}{l}\text { Identification of interactions between } \\
\text { manufacturing and logistical } \\
\text { industries }\end{array}$ & Grey DANP & (Jiang et al, 2018) \\
\hline Transport management & $\begin{array}{l}\text { WSM; REMBRANDT; } \\
\text { Delphi; Fuzzy TOPSIS; } \\
\text { AHP; SAW; } \\
\text { PROMETHEE; }\end{array}$ & $\begin{array}{l}\text { (Jeon et al, 2010); } \\
\text { (Cadena \& Magro, } \\
\text { 2015); (Awasthi \& } \\
\text { Chauhan, 2011); } \\
\text { (Castillo \& Pitfield, }\end{array}$ \\
\hline
\end{tabular}




\begin{tabular}{|c|c|c|}
\hline $\begin{array}{l}\text { Field of application for the MCDM } \\
\text { method }\end{array}$ & MCDM method & Literature \\
\hline & $\begin{array}{l}\text { ELECTRE I; } \\
\text { Modified ELECTRE I; } \\
\text { Fuzzy Delphi; } \\
\text { DEMATEL - ANP }\end{array}$ & $\begin{array}{l}\text { 2010); (Simongáti, } \\
\text { 2010); (Bojković et } \\
\text { al, 2010); (Dimić et } \\
\text { al, 2016); (Awasthi } \\
\text { \& Chauhan, 2012) }\end{array}$ \\
\hline Vehicle evaluation & WSM; PROMETHEE; & $\begin{array}{l}\text { (Mitropoulos \& } \\
\text { Prevedouros, } \\
\text { 2016); (Safaei } \\
\text { Mohamadabadi et } \\
\text { al, 2009) }\end{array}$ \\
\hline $\begin{array}{l}\text { Location Evaluation Problem for } \\
\text { Logistical Center Construction }\end{array}$ & $\begin{array}{l}\text { Fuzzy Delphi; Fuzzy } \\
\text { Delphi ANP; Fuzzy } \\
\text { Delphi VIKOR; Fuzzy } \\
\text { MAGDM; Fuzzy ARAS; } \\
\text { AHP; DEMATEL- } \\
\text { MAIRCA }\end{array}$ & $\begin{array}{l}\text { (Zečević et al, } \\
\text { 2017); (Rao et al, } \\
\text { 2015); (Turskis \& } \\
\text { Zavadskas, 2010); } \\
\text { (Pamučar et al, } \\
\text { 2018a); } \\
\text { (Noureddine \& } \\
\text { Ristic, 2019); } \\
\text { (Puška et al, 2018); } \\
\text { (Fazlollahtabar, } \\
\text { 2018) }\end{array}$ \\
\hline $\begin{array}{l}\text { Assessment and construction of } \\
\text { transport infrastructure }\end{array}$ & $\begin{array}{l}\text { AHP; FAHP; } \\
\text { REMBRANDT; } \\
\text { WASPAS }\end{array}$ & $\begin{array}{l}\text { (Barić et al, 2016); } \\
\text { (Inti \& Tandon, } \\
\text { 2017); (López \& } \\
\text { Monzón, 2010); } \\
\text { (Jones et al, 2013); } \\
\text { (Stanujkić \& } \\
\text { Karabašević, } \\
\text { 2018); (Pamučar et } \\
\text { al, 2018b) }\end{array}$ \\
\hline $\begin{array}{l}\text { Selection and ranking of military } \\
\text { vehicles }\end{array}$ & $\begin{array}{l}\text { AHP-DEA; neuro-fuzzy } \\
\text { sistem }\end{array}$ & $\begin{array}{l}\text { (Starcevic et al, } \\
\text { 2019); (Pamucar et } \\
\text { al, 2013) }\end{array}$ \\
\hline
\end{tabular}

Based on the presented literature analysis, we can conclude that the most frequently used method for solving problems in the field of transport and logistics in the past ten years was the AHP method. However, the AHP method requires the use of $n(n-1) / 2$ comparison of criteria pairs. A large number of comparisons makes the application of the model more complicated, especially in cases with a larger number of criteria. For this reason, the use of this method is not advised in cases with a larger number of criteria. The model which eliminates the abovementioned drawback of the AHP method is the BWM method. But even with this 
fact, and the numerous advantages of the BWM over the AHP method we can see that the BWM has not been used in the field in question. Therefore, a logical need arises for the development of MCDM models which imply the implementation of all BWM advantages. In addition to the BWM method, by analyzing the literature, we can see that the COPRAS (COmpressed PRoportional ASsessment) method has not been used either, even though it falls into models which yield stable results. Considering that in the presented literature there are no examples of either BWM or COPRAS models for off-road vehicle assessment in either civilian or military organizations, the need for their application is imposed. The application of the BWM-COPRAS model fills the gap that exists in the literature which deals with this field.

\section{BWM-COPRAS multi-criteria model}

As previously emphasized, the BWM-COPRAS implies the use of two methods, the BWM method for determining the weight coefficients of criteria, and the COPRAS method for assessing, i.e. ranking alternatives (Figure 1)

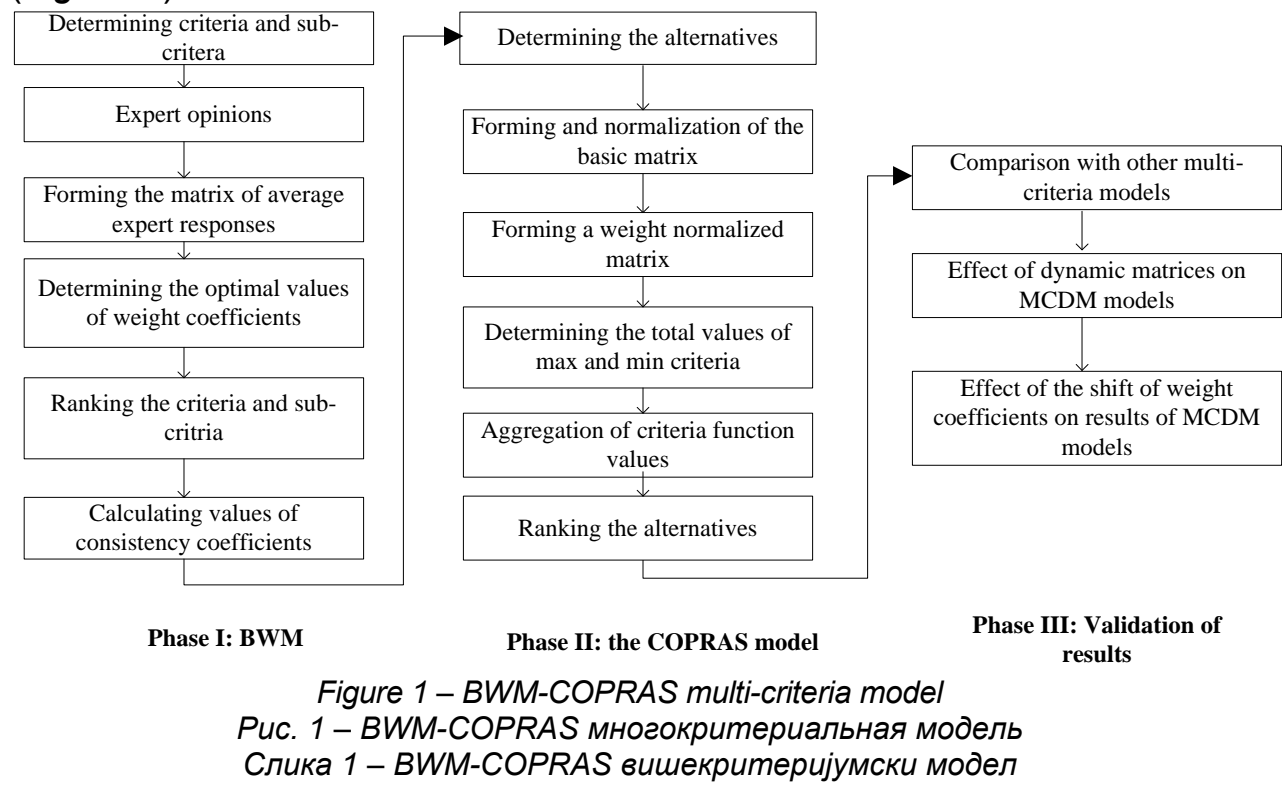

The model contains three phases. Phase one calculates the optimal values of the weight coefficients of criteria through the application of the BWM. The end results of the BWM method are the values of the weight coefficients of criteria. The output results of the BWM, the weight 
coefficients, are further processed through the COPRAS method algorithm. In phase two, the COPRAS method is used to rank the alternatives. Phase three is the validation of the results. The next section shows the algorithms of the BWM and COPRAS methods.

\section{Best-Worst method}

The following section contains the algorithm of the BWM method for determining the weight coefficients of evaluation criteria (Rezaei, 2015), (Stević et al, 2018).

\section{Algorithm: BWM}

Input: Expert pairwise comparison of criteria

Output: Optimal values of the weight coefficients of criteria/sub-criteria

Step 1: The identification of the selected criteria as a set of the criteria related to the topic. The set of the criteria can be evaluated as $C_{1}, C_{2}, C_{3}, C_{4} \ldots \ldots C_{n}$.

Step 2: Finding the best and the worst criteria. As mentioned above, it should be done by experts and the involved decision-makers.

Step 3: The creation of a matrix of the preference of the best criterion over all the other criteria (BO vector) by applying numbers between 1 and 9:

$$
A_{b}=\left(a_{1 B}, a_{2 B}, a_{3 B}, \ldots a_{n B}\right)
$$

Step 4: The creation of a matrix of the preference of the worst criterion over all the other criteria (OW vector) by applying numbers between 1 and 9 .

$$
A_{b}=\left(a_{1 W}, a_{2 W}, a_{3 W}, \ldots a_{n W}\right)
$$

Step 5: Generating the relative importance of the criteria through calculating the final and optimal weights for the criteria. The weights will show the same as: ${ }_{1}, w_{2}, w_{3} \ldots . . w_{n}$. $\min \xi$

s.t.

$$
\begin{aligned}
& \left|\frac{w_{B}}{w_{j}}-a_{B j}\right| \leq \xi, \forall j \\
& \left|\frac{w_{j}}{w_{w}}-a_{j W}\right| \leq \xi, \forall j \\
& \sum_{j=1}^{n} w_{j}=1 \\
& w_{j} \geq 0 \quad \forall j
\end{aligned}
$$

Step 6: The same as with the AHP, there is a consistency index shown in Table 2. The consistency ratio should be calculated as follows:

Consistency $=\frac{\xi}{\text { Consistency index }}$ 
For different values $a_{B W} \in\{1,2, \ldots, 9\}$ we get the maximum values $\xi(\max \xi)$. Table 2 contains the maximum values of $\xi$ for different values of $a_{B W} \in\{1,2, \ldots, 9\}$.

Table 2 - Consistency Index values (Cl)

Таблица 2 - Значения степени надежности (CI)

Табела 2 - Вредности степена конзистентности (Cl)

\begin{tabular}{ccccccc}
\hline$a_{B W}$ & 1 & 2 & $\ldots$ & 7 & 8 & 9 \\
\hline $\mathrm{Cl}(\max \xi)$ & 0.00 & 0.44 & $\ldots$ & 3.73 & 4.47 & 5.23
\end{tabular}

Based on $\mathrm{Cl}$, we get the consistency ratio (CR) which takes the values of interval $[0,1]$, where the values closer to zero indicate a high consistency, and the CR values closer to one indicate a low consistency.

\section{COPRAS Method}

Within the decision-making theory, there is a large number of multicriteria decision making methods (MCDM) which support us in solving different problems. The COPRAS method (Zavadskas \& Kaklauskas, 1996 ) is one of newer methods which is increasingly used in literature (Chatterjee et al, 2018), (Pamučar et al, 2018a), (Mukhametzyanov \& Pamučar, 2018). Each MCDM method is characterized by a specific mathematical apparatus. The COPRAS method is partly characterized by a more complicated procedure of criteria function value aggregation, and the simplified procedure of data normalization (the nature of the criteria is irrelevant - $\min / \max$ ). The following section succinctly displays the mathematical apparatus of the COPRAS method.

The problem is formally presented by choosing one of the $m$ options (alternatives), $A_{i}, i=1,2, \ldots, m$ which are assessed and compared among each other based on the $n$ criterion $\left(X_{j}, j=1,2, \ldots, n\right)$ whose values are familiar. The alternatives are presented as vectors $x_{i j}$ where $x_{i j}$ is the value of the $i$ alternative according to the $j$ criteria. Since the criteria have varying impacts on the final assessment of the alternatives, each criterion is assigned a weight coefficient $w_{j}, j=1,2, \ldots, n$ (where $\sum_{j=1}^{n} w_{j}=1$ ) which reflects its relative value in assessing the alternatives.

Step 1. Normalization of the basic matrix. The first step of the COPRAS method includes the normalization of the elements of the basic decision-making matrix $(X)$. 


$$
\begin{aligned}
& \begin{array}{lllll}
C_{1} & C_{2} & \ldots & C_{n}
\end{array} \\
& X=\begin{array}{c}
A_{1} \\
A_{2} \\
\ldots \\
A_{m}
\end{array}\left[\begin{array}{cccc}
x_{11} & x_{12} & \ldots & x_{1 n} \\
x_{21} & x_{22} & & x_{2 n} \\
\ldots & \ldots & \ldots & \ldots \\
x_{m 1} & x_{m 2} & \ldots & x_{m n}
\end{array}\right]
\end{aligned}
$$

The main goal of criteria value normalization is the transformation of different values of criteria ("benefit" or "cost") into values which allow mutual comparison. The normalization values are shown in the matrix $D$.

$$
\begin{array}{lllll}
C_{1} & C_{2} & \ldots & C_{n}
\end{array}
$$

$D=\begin{gathered}A_{1} \\ A_{2} \\ \ldots \\ A_{m}\end{gathered}\left[\begin{array}{cccc}x_{11} & x_{12} & \ldots & x_{1 n} \\ x_{21} & x_{22} & & x_{2 n} \\ \ldots & \ldots & \ldots & \ldots \\ x_{m 1} & x_{m 2} & \ldots & x_{m n}\end{array}\right]$

The elements of the normalized matrix $\left(x_{i j}\right)$ are obtained by applying additive normalization:

$$
x_{i j}^{\prime}=\frac{x_{i j}}{\sum_{i=1}^{m} x_{i j}}
$$

where $x_{i j}$ represents the elements of the basic decision-making matrix $(X), x_{i j}$ represents the normalized values of the elements from the basic decision-making matrix, and $m$ represents the total number of alternatives.

Step 2. Forming of the weighted normalized matrix. In the second step, a weighted normalized matrix $(Z)$, obtained by multiplying the elements of the normalized matrix $(D)$ with the weight coefficients of the criteria $\left(w_{j}\right)$, is constructed.

$$
Z=\left[\begin{array}{cccc}
z_{11} & z_{12} & \ldots & z_{1 n} \\
z_{21} & z_{22} & & z_{2 n} \\
\ldots & \ldots & \ldots & \ldots \\
z_{m 1} & z_{m 2} & \ldots & z_{m n}
\end{array}\right]=\left[\begin{array}{cccc}
w_{1} \cdot x_{11} & w_{2} \cdot x_{12} & \ldots & w_{n} \cdot x_{1 n} \\
w_{1} \cdot x_{21} & w_{2} \cdot x_{22} & \ldots & w_{n} \cdot x_{2 n} \\
\ldots & \ldots & \ldots & \ldots \\
w_{1} \cdot x_{m 1} & w_{2} \cdot x_{m 2} & \ldots & w_{n} \cdot x_{m n}
\end{array}\right]
$$

where $n$ is the total number of criteria, and $m$ is the total number of alternatives.

Step 3. In the following, third step, the values of the $Z$ matrix are summed up in columns. The values are summed up depending on which 
criteria group they belong to ("benefit" $\rightarrow$ max or "cost" $\rightarrow \min$ ). The values of the benefit criterion (higher criterion value is desirable) are obtained by applying formula (5) or formula (6):

$S_{i}^{+}=\sum_{z_{i}=+} z_{i j}$

where $z_{i}=+$ is the sum of the benefit criteria, or:

$S_{i}^{+}=\sum_{i=1}^{k} x_{i j} \cdot q_{j}$

where $k$ is the total number of the benefit criteria.

The values of the cost criterion (lower criterion value is desirable) is obtained by applying formula (7) or formula (8):

$S_{i}^{-}=\sum_{z_{i}=-} z_{i j}$

where $z_{i}=-$ is the aggregate of the cost criteria, or:

$S_{i}^{-}=\sum_{i=1}^{p} \tilde{x}_{i j} \cdot q_{j}$

where $p$ is the total number of the cost criteria.

Step 4. Aggregation of the criteria function values. In step four, by applying formula (9), we determine the significance (influence) of each of the given alternatives from the set of the compared alternatives:

$Q_{i}=S_{i}^{+}+\frac{S_{\min }^{-} \sum_{i=1}^{m} S_{i}^{-}}{S_{i}^{-} \sum_{i=1}^{m}\left(\frac{S_{\min }^{-}}{S_{i}^{-}}\right)}=S_{i}^{+}+\frac{\sum_{i=1}^{m} S_{i}^{-}}{S_{i}^{-} \sum_{i=1}^{m} \frac{1}{S_{i}^{-}}}$

Step 5. Ranking of alternatives. In the final, fifth step, the ranking of alternatives is performed based on the values of the criterion function which is assigned to each alternative. The end-values of the criteria functions of alternatives are gained by applying formula (10):

$N_{i}=\frac{Q_{i}}{Q_{\max }} \cdot 100 \%$

\section{Application of the BWM-COPRAS model to off-road} vehicle selection in the SAF

Military cargo motor vehicles for passenger transport are only one of the vehicles categories used in the SAF. Since this paper deals only with this vehicle category, the following section will briefly introduce the 
classification of vehicles in the SAF and the types of vehicles used in the SAF as well as in other militaries across the world.

\section{Classification of vehicles}

The classification of motor vehicles and other means of transportation that use liquid fuels in the MoD and the SAF (except waterborne vessels, aircraft, stationary aggregates and boiler rooms), aims to group the encompassed vehicles according to the criterion of purpose or according to similar technical characteristics.

The classification includes the division of vehicles into classes, types, groups and the assignment of numbers for marking them: I classes of vehicles are marked with numbers 1-9; II -types of vehicles within classes are marked with numbers 01-99 and III -groups of vehicles within types are marked with numbers 01-99. This paper deals with vehicles that belong to the first group of the aforementioned classification as shown in Table 3.

Table 3 - Classification of off-road vehicles for passenger transport in the SAF Таблица 3 - Классификация внедорожных транспортных средств для перевозки пассажиров в ВСРC

Табела 3 - Класификација теренских возила за транспорт путника у ВС

\begin{tabular}{lll}
\hline Mark & \multicolumn{3}{l}{ Vehicle description } \\
\hline \multirow{3}{*}{1.04} & 01 & Off-road vehicle for passenger transport, up to 5 seats; \\
& 02 & Off-road vehicle for passenger transport, 6 to 8 seats; \\
& 03 & Off-road vehicle for passenger transport, more than 8 seats; \\
& 04 & Off-road vehicle for passenger transport, with protection. \\
\hline
\end{tabular}

The supply of this vehicle category from the SAF fleet is low and amounts to approximately $43 \%$, while the total number (of vehicles from the prescript fleet) is $92 \%$. The structure of vehicles from this category in the SAF is also inhomogeneous, i.e. they are of different brands and types, mostly obtained more than 30 years ago. The most prominent brands of manufacturers are: PUCH (around 33\%), PINZGAUER (around $27 \%$ ), LADA (around 14\%) and LANDROVER (around 10\%). The inhomogeneity of the fleet vehicles complicates the maintenance process of these vehicles. The average functionality of off-road vehicles for passenger transport in the SAF is approximately $66 \%$. The average age of off-road vehicles for passenger transport in SAF units is 26.9 years. It is especially important to stress that approximately $80 \%$ of this category is older than 12 years, which is also the designed lifespan of these vehicles. In addition to the abovementioned statistical data, it is 
necessary to point out that an average off-road vehicle for passenger transport in SAF has crossed approximately 141,000 kilometers, where the vehicles older than 12 years have on average crossed $162,728 \mathrm{~km}$, and vehicles less than 12 years old $56,000 \mathrm{~km}$.

\section{Defining the criteria for off-road vehicle selection and} characteristics of alternatives

Given than in the publicly available literature there are not a large number of papers dealing with the topic of military off-road vehicle selection, the criteria have been defined based on the available literature, internal regulations and requirements of the SAF. The chosen criteria are shown in Figure 2. In addition to the abovementioned criteria, criteria such as equipment with the AC, GPS, traction-control system, etc. were excluded.

Goal

Sub-criteria

Alternatives

Selection of off-road

motor vehicle for

passenger transport

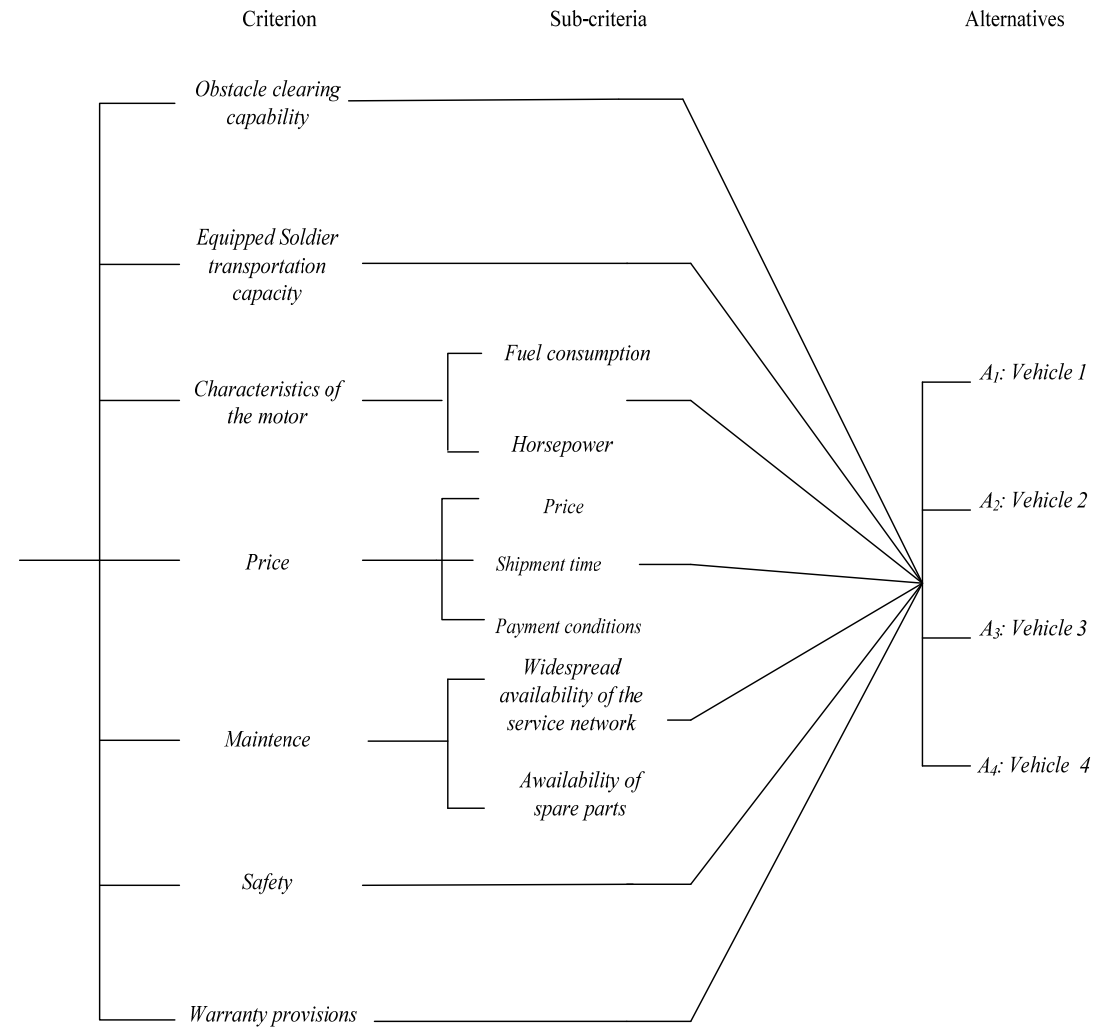

Figure 2 - Hierarchical model for vehicle selection

Puc. 2 - Иерархическая модель для выбора транспортного средства

Слика 2 - Хијерархијски модел за избор возила 
The first level represents a goal which is a choice between the given vehicle types, while the second level includes 7 criteria for vehicle selection: obstacle clearing capability (C1), equipped soldier transportation capacity (C2), characteristics of the motor (C3), price (C4), maintenance (C5), safety (C6), and warranty provisions (C7). The third level consists of seven sub-criteria that are sorted within the group of the main criteria, while the potential vehicle types are shown on the fourth level.

By comparing the characteristics of the vehicles used by the SAF and modern vehicles used for the same purpose, a conclusion is drawn that a modernization of SAF's fleet vehicles is needed. Modern vehicles have significantly improved characteristics when looking at maneuverability, tank capacity and horsepower. Since there is no consensus among manufacturers concerning the evaluation of the abovementioned vehicle types, as well as because of data confidentiality policies, this paper will not talk about specific types of vehicles - instead, the vehicles will be marked as vehicle 1 - vehicle 4 .

Vehicle 1 (A1) has the following technical characteristics: its ability to clear obstacles is higher than that of vehicle 2 and lower than that of vehicle 4; the vehicle can simultaneously carry four persons; the level of passenger and cargo security is higher compared to other given types of vehicles; it has $190 \mathrm{HP}$, and fuel consumption is $23.75 \mathrm{l} / \mathrm{km}$; the price of the vehicle is $15,785,100$ RSD with the possibility of payment in 18 installments without interest; the shipment deadline is 6 months and it has a 24 month guarantee; and the availability of the service network and spare parts is poorer than for other given vehicle types.

Vehicle 2 (A2) has the following technical characteristics: the ability to clear obstacles is the lowest with this vehicle; the vehicle can simultaneously carry 6 persons, and the security of the passengers and cargo is on a high level; the engine has $122 \mathrm{HP}$, and consumes fuel at the rate of $10.1 \mathrm{l} / \mathrm{km}$; the price of the vehicle is $13,702,500 \mathrm{RSD}$ with the possibility of payment in 18 installments without interest; the shipment deadline is 4 months and it has a 24-month guarantee; the widespread availability of the service network and the availability of spare parts is better than for vehicle 1 , but worse than for other given types of vehicles.

Vehicle 3 (A3) has the following technical characteristics: this vehicle's ability to clear obstacles is the same as with vehicle 1 ; the 
vehicle can simultaneously carry 4 persons, the security of passengers and cargo is lower compared to vehicle 1 and vehicle 2; the engine has $177 \mathrm{HP}$, and consumes fuel at the rate of $10.4 \mathrm{l} / \mathrm{km}$; the price of the vehicle is $14,210,000$ RSD with the possibility of payment in 12 installments without interest; the shipment deadline is 4 months, and it has a 12-month guarantee; the widespread availability of the service network and the availability of spare parts is better than with all other given vehicles.

Vehicle 4 (A4) has the following characteristics: the ability to clear obstacles is on a higher level than with other vehicles; the vehicle can simultaneously carry 6 persons; the level of passenger and cargo security is the lowest compared to all other vehicle types; the engine has $268 \mathrm{HP}$ and consumes power at the rate of $9.5 \mathrm{l} / \mathrm{km}$; the price of the vehicle is $10,380,000$ RSD with the possibility of payment in 24 installments without interest; the shipment deadline is 6 months, and it has a 60-month guarantee; the widespread availability of the service network and the availability of spare parts is better than with vehicle 1 and vehicle 2, but worse than with vehicle 3 .

\section{Vehicle assessment through the application of the BWM- COPRAS model}

This research includes three groups of experts. Within every criteria/sub-criteria group experts have defined the best (B) and worst (W) criterion/sub-criterion. Based on this, the $\mathrm{BO}$ and $\mathrm{OW}$ vectors were defined for $\mathrm{B}$ and W criteria/sub-criteria. The criteria/sub-criteria assessment was performed through the application of [1,9] scale: 1 very low influence; 2 - low influence;...; 8 - high influence; 9 - very high influence. The values of $\mathrm{BO}$ and $\mathrm{OW}$ vectors within the groups of criteria/sub-criteria are shown in Table 4.

The optimal values of the weight coefficients of the criteria/subcriteria vectors are calculated based on the defined ratios from Table 5. This is how the four non-linear models for calculating the optimal values of the criteria/sub-criteria weight coefficients were formed. 
Table $4-B O$ and $O W$ vectors

Таблица 4 - BO и OW векторы

Табела 4 - BO и OW вектори

\begin{tabular}{|c|c|c|c|}
\hline \multicolumn{4}{|l|}{ Criteria } \\
\hline The best: C4 (Price) & $\begin{array}{l}\text { Expert } \\
\text { evaluation }\end{array}$ & $\begin{array}{l}\text { The worst: C3 } \\
\text { (Characteristics of the } \\
\text { motor) }\end{array}$ & Expert evaluation \\
\hline $\begin{array}{l}\text { C1 (Obstacle clearing } \\
\text { capability) }\end{array}$ & $5 ; 6 ; 6$ & $\begin{array}{l}\text { C1 (Obstacle clearing } \\
\text { capability) }\end{array}$ & $4 ; 4 ; 4$ \\
\hline $\begin{array}{l}\text { C2 (Equipped soldier } \\
\text { transportation } \\
\text { capacity) }\end{array}$ & $7 ; 7 ; 8$ & $\begin{array}{l}\text { C2 (Equipped soldier } \\
\text { transportation } \\
\text { capacity) }\end{array}$ & $3 ; 2 ; 2$ \\
\hline $\begin{array}{l}\text { C3 (Characteristics of } \\
\text { the motor) }\end{array}$ & $9 ; 9 ; 9$ & C4 (Price) & $9 ; 9 ; 9$ \\
\hline C5 (Maintenance) & $2 ; 2 ; 2$ & C5 (Maintenance) & $7 ; 7 ; 7$ \\
\hline C6 (Safety) & $3 ; 5 ; 2$ & C6 (Safety) & $5 ; 5 ; 7$ \\
\hline $\begin{array}{l}\text { C7 (Warranty } \\
\text { provisions) }\end{array}$ & $3 ; 4 ; 4$ & $\begin{array}{l}\text { C7 (Warranty } \\
\text { provisions) }\end{array}$ & $5 ; 6 ; 6$ \\
\hline \multicolumn{4}{|c|}{ C3 (Characteristics of the motor) } \\
\hline $\begin{array}{l}\text { The best: C31 (Fuel } \\
\text { consumption) }\end{array}$ & $\begin{array}{l}\text { Expert } \\
\text { evaluation }\end{array}$ & $\begin{array}{l}\text { The best: C32 } \\
\text { (horsepower) }\end{array}$ & Expert evaluation \\
\hline C32 (horsepower) & $4 ; 3 ; 2$ & $\begin{array}{l}\text { C31 (Fuel } \\
\text { consumption) }\end{array}$ & $2 ; 4 ; 3$ \\
\hline \multicolumn{4}{|l|}{ C4 (price) } \\
\hline $\begin{array}{l}\text { The best: } \mathrm{C} 41 \\
\text { (Price) }\end{array}$ & $\begin{array}{l}\text { Expert } \\
\text { evaluation }\end{array}$ & $\begin{array}{l}\text { The best: C42 } \\
\text { (shipment time) }\end{array}$ & Expert evaluation \\
\hline C42 (shipment time) & $6 ; 5 ; 5$ & C41 (price) & $6 ; 5 ; 7$ \\
\hline $\begin{array}{l}\text { C43 (payment } \\
\text { conditions) }\end{array}$ & $3 ; 3 ; 2$ & $\begin{array}{l}\text { C43 (payment } \\
\text { conditions) }\end{array}$ & $4 ; 2 ; 6$ \\
\hline \multicolumn{4}{|l|}{ C5 (maintenance) } \\
\hline $\begin{array}{l}\text { The best:C51 } \\
\text { (widespread } \\
\text { availability of the } \\
\text { service network) }\end{array}$ & $\begin{array}{l}\text { Expert } \\
\text { evaluation }\end{array}$ & $\begin{array}{l}\text { The best: C52 } \\
\text { (availability of spare } \\
\text { parts) }\end{array}$ & Expert evaluation \\
\hline $\begin{array}{l}\text { C52 (availability of } \\
\text { spare parts) }\end{array}$ & $2 ; 3 ; 3$ & $\begin{array}{l}\text { C51 (widespread } \\
\text { availability of the } \\
\text { service network) }\end{array}$ & $2 ; 3 ; 5$ \\
\hline
\end{tabular}


Medium values of expert evaluations are shown in Table 5.

Table 5 - Medium values of the $B O$ and $O W$ vectors Таблица 5 - Средние значения ВО и ОW векторов Табела 5 - Средње вредности BO и OW вектора

\begin{tabular}{|c|c|c|c|}
\hline \multicolumn{4}{|l|}{ Criteria } \\
\hline The best : C4 (Price) & Medium value & $\begin{array}{l}\text { The worst: C3 } \\
\text { (Characteristics of the } \\
\text { motor) }\end{array}$ & Medium value \\
\hline $\begin{array}{l}\text { C1 (Obstacle clearing } \\
\text { capability) }\end{array}$ & 5.7 & $\begin{array}{l}\text { C1 (Obstacle clearing } \\
\text { capability) }\end{array}$ & 4 \\
\hline $\begin{array}{l}\text { C2 (Equipped soldier } \\
\text { transportation capacity) }\end{array}$ & 7.33 & $\begin{array}{l}\text { C2 (Equipped soldier } \\
\text { transportation capacity) }\end{array}$ & 2.33 \\
\hline $\begin{array}{l}\text { C3 (Characteristics of } \\
\text { the motor) }\end{array}$ & 9 & C4 (Price) & 9 \\
\hline C5 (Maintenance) & 2 & C5 (Maintenance) & 7 \\
\hline C6 (Safety) & 3.33 & C6 (Safety) & 5.67 \\
\hline C7 (Warranty provisions) & 3.67 & C7 (Warranty provisions) & 5.67 \\
\hline \multicolumn{4}{|c|}{ C3 (Characteristics of the motor) } \\
\hline $\begin{array}{l}\text { The best: C31 (fuel } \\
\text { consumption) }\end{array}$ & Medium value & $\begin{array}{l}\text { The worst: C32 } \\
\text { (horsepower) }\end{array}$ & Medium value \\
\hline C32 (horsepower) & 3 & C31(fuel consumption) & 3 \\
\hline \multicolumn{4}{|l|}{ C4 (price) } \\
\hline The best: C41 (price) & Medium value & $\begin{array}{l}\text { The worst: C42 } \\
\text { (shipment time) }\end{array}$ & Medium value \\
\hline C42 (shipment time) & 5.33 & C41 (price) & 6 \\
\hline $\begin{array}{l}\text { C43 (payment } \\
\text { conditions) }\end{array}$ & 6.67 & $\begin{array}{l}\text { C43 (payment } \\
\text { conditions) }\end{array}$ & 4 \\
\hline \multicolumn{4}{|l|}{ C5 (maintenance) } \\
\hline $\begin{array}{l}\text { The best: C51 } \\
\text { (widespread availability } \\
\text { of the service network) }\end{array}$ & Medium value & $\begin{array}{l}\text { The worst: C52 } \\
\text { (availability of spare } \\
\text { parts) }\end{array}$ & Medium value \\
\hline $\begin{array}{l}\text { C52 (availability of spare } \\
\text { parts) }\end{array}$ & 2.67 & $\begin{array}{l}\text { C51 (widespread } \\
\text { availability of the service } \\
\text { network) }\end{array}$ & 3.33 \\
\hline
\end{tabular}


Model 1 (Criteria)

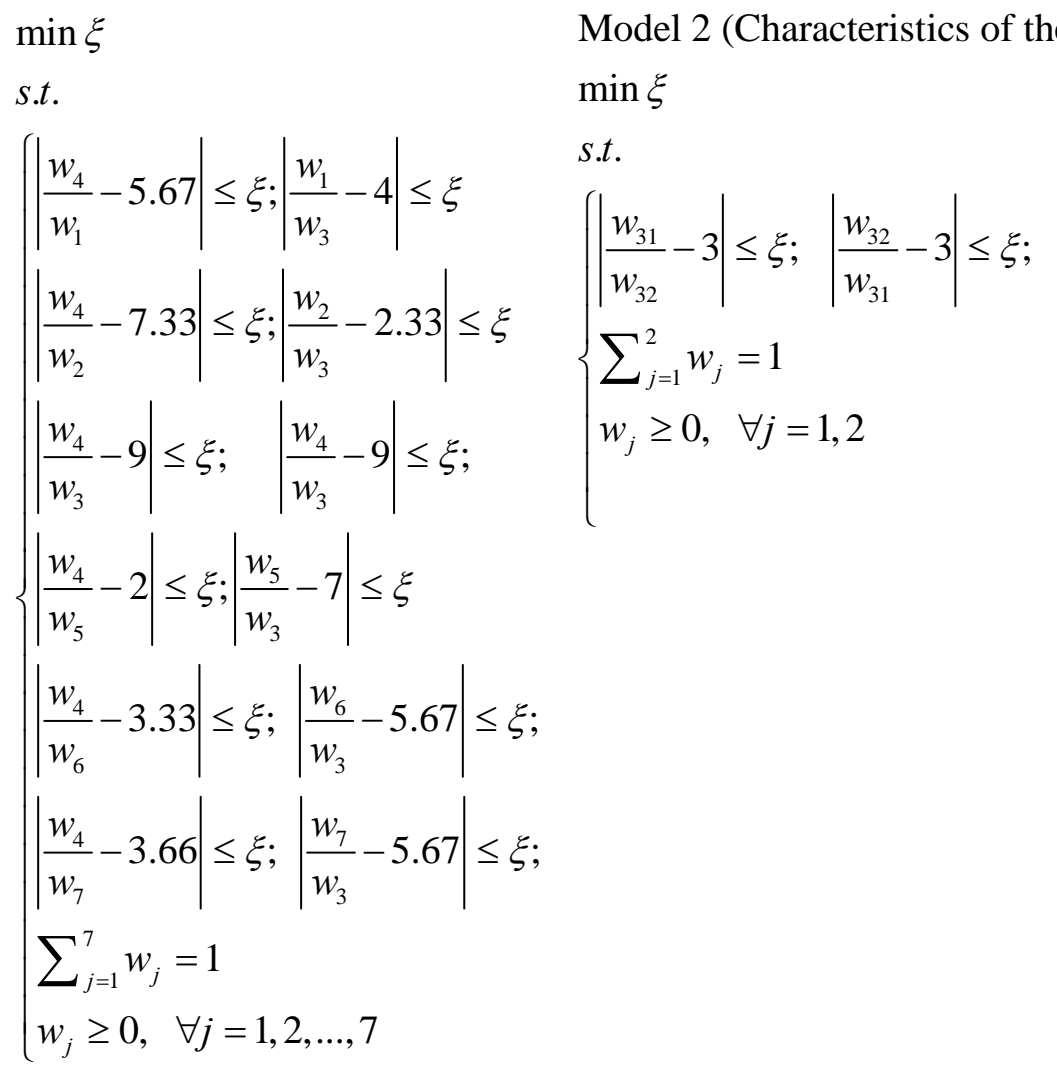

\section{Model 3 (Price)}

$\min \xi$

s.t.

$$
\left\{\begin{array}{l}
\left|\frac{w_{41}}{w_{42}}-5.33\right| \leq \xi ;\left|\frac{w_{41}}{w_{42}}-6\right| \leq \xi ; \\
\left|\frac{w_{41}}{w_{43}}-6.67\right| \leq \xi ;\left|\frac{w_{43}}{w_{42}}-4\right| \leq \xi ; \\
\sum_{j=1}^{3} w_{j}=1 \\
w_{j} \geq 0, \quad \forall j=1,2,3
\end{array}\right.
$$

Model 4 (Maintenance) $\min \xi$

s.t.

$$
\left\{\begin{array}{l}
\left|\frac{w_{51}}{w_{52}}-2.67\right| \leq \xi ;\left|\frac{w_{51}}{w_{52}}-3.33\right| \leq \xi \\
\sum_{j=1}^{2} w_{j}=1 \\
w_{j} \geq 0, \quad \forall j=1,2
\end{array}\right.
$$




\begin{tabular}{|c|c|c|c|}
\hline \multicolumn{4}{|c|}{$\begin{array}{l}\text { The optimal values of the weight coefficients were obtained based } \\
\text { on the aforementioned models, Table } 6 \text {. }\end{array}$} \\
\hline \multicolumn{4}{|c|}{$\begin{array}{l}\text { Table } 6 \text { - Optimal values of the sub-criteria } \\
\text { Таблица } 6 \text { - Оптимальные значения субкритериев } \\
\text { Табела } 6 \text { - Оптималне вредности поткритеријума }\end{array}$} \\
\hline $\begin{array}{l}\text { Criteria/Sub- } \\
\text { criteria }\end{array}$ & Local weights & Global weights & Rank \\
\hline C1 & 0.077 & 0.077 & 5 \\
\hline C2 & 0.059 & 0.059 & 6 \\
\hline C3 & 0.033 & - & - \\
\hline C31 & 0.750 & 0.025 & 10 \\
\hline C32 & 0.250 & 0.008 & 11 \\
\hline C4 & 0.365 & - & - \\
\hline C41 & 0.754 & 0.276 & 1 \\
\hline C42 & 0.097 & 0.035 & 9 \\
\hline C43 & 0.149 & 0.054 & 7 \\
\hline C5 & 0.217 & - & - \\
\hline C51 & 0.750 & 0.163 & 2 \\
\hline C52 & 0.250 & 0.054 & 8 \\
\hline $\mathrm{C} 6$ & 0.130 & 0.130 & 3 \\
\hline $\mathrm{C} 7$ & 0.118 & 0.118 & 4 \\
\hline
\end{tabular}

Table 6 shows the global and local values of the criteria/sub-criteria weight coefficients. The global values were obtained through multiplication of the weight criteria coefficients and the weight sub-criteria coefficients. The global weight values are further used to assess the alternatives in the multi-criteria model.

By solving the non-linear models the values $\xi_{\text {Критеријми }}^{*}=0.06868$, $\xi_{\text {Каракт.мотора }}^{*}=0, \xi_{\text {цена }}^{*}=0.238385$ and $\xi_{\text {оррмсаване }}^{*}=0.33$ are obtained. The $\xi^{*}$ values are used for defining the consistency coefficients. Using the 
obtained values of $\xi^{*}$, the values of the consistency index and the consistency ratio were defined, Table 7.

Table 7 - Values of the Consistency index and the Consistency ratio Таблица 7 - Значения степени надежности и индекса надежности Табела 7 - Вредности степена и индекса конзистентности

\begin{tabular}{lllll}
\hline $\begin{array}{l}\text { Sub-criteria } \\
\text { level }\end{array}$ & $C_{\text {criteria }}$ & $\begin{array}{l}C_{\text {characteristics of the }} \\
\text { motor }\end{array}$ & $C_{\text {price }}$ & $C_{\text {maintenance }}$ \\
\hline$a_{B W}$ & 9 & 3 & 6.67 & 3.33 \\
$\mathrm{Cl}$ & 5.23 & 1.00 & 3.335 & 1.11 \\
$\mathrm{CR}$ & 0.013 & 0.000 & 0.071 & 0.297 \\
\hline
\end{tabular}

After obtaining the weight coefficient values, the COPRAS method is used for choosing the best alternative. The first step is to form the basic matrix $(X)$

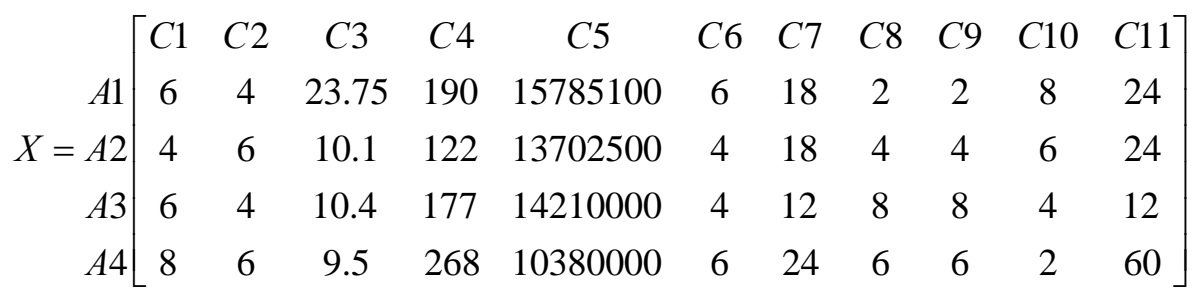

In the first phase, by applying formula (3), the normalization of the basic decision-making matrix $(X)$ is performed. This is how we get the normalized matrix $(D)$.

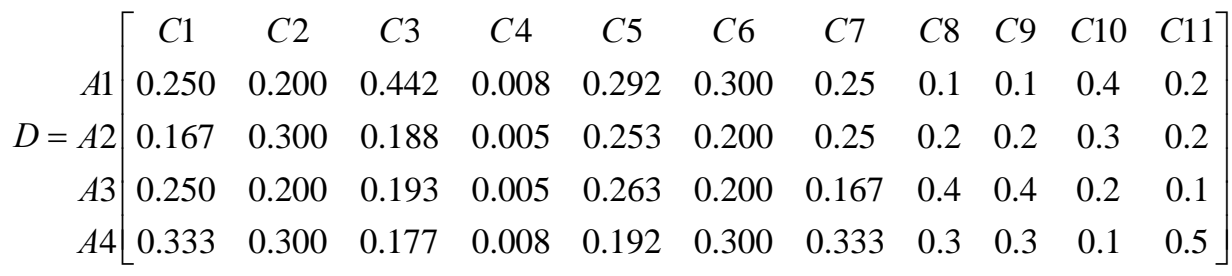

In the second phase, we perform the multiplication of the value of the matrix $(D)$ with the weight coefficients by applying formula (4) and form the weight-normalized matrix $(Z)$. 


\begin{tabular}{|c|c|c|c|c|c|c|c|c|c|c|c|}
\hline & $C 1$ & $C 2$ & $C 3$ & $C 4$ & $C 5$ & $C 6$ & $C 7$ & $C 8$ & $C 9$ & $C 10$ & $C 11$ \\
\hline$A 1$ & 0.019 & 0.012 & 0.011 & 0.000 & 0.081 & 0.011 & 0.014 & 0.016 & 0.005 & 0.052 & 0.024 \\
\hline$=A 2$ & 0.013 & 0.018 & 0.005 & 0.000 & 0.070 & 0.007 & 0.014 & 0.033 & 0.011 & 0.039 & 024 \\
\hline$A 3$ & 0.019 & 0.012 & 0.005 & 0.000 & 0.073 & 0.007 & 0.009 & 0.065 & 0.022 & 0.026 & 0.012 \\
\hline$A 4$ & 0.026 & 0.018 & 0.004 & 0.000 & 0.053 & 0.011 & 0.018 & 0.049 & 0.016 & 0.013 & 0.05 \\
\hline
\end{tabular}

In the third phase, we sum up the values of the $Z$ matrix by columns. The values are summed up based on which criterion group they belong to (max or $\min$ ). The total values of the max and min criteria are shown in the following matrix.
$A 1\left[\begin{array}{cc}S i+ & S i- \\ 0.2037 & 0.0403\end{array}\right]$
$A 2 \quad 0.1786 \quad 0.0531$
A3 0.16790 .0812
$A 4\left[\begin{array}{ll}0.1890 & 0.0774\end{array}\right]$

In the fourth phase, we apply formula (9) to define the significance of each of the considered alternatives from the set of alternatives being compared. In the end, the ranking of the alternatives is performed based on the value of the criterion function that is assigned to every alternative. The final values of the COPRAS method and the alternative ranks are shown in the $Q$ matrix.

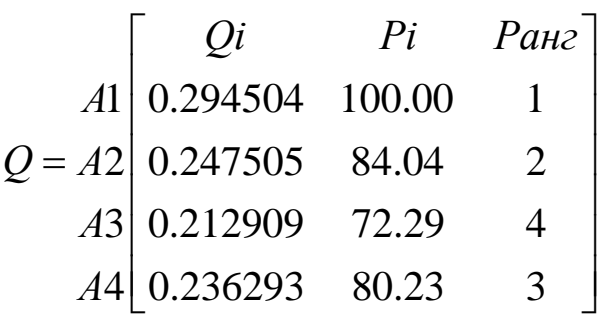

Based on the criteria function values, the final rank of the alternatives is defined: $\mathrm{A} 1>\mathrm{A} 2>\mathrm{A} 4>\mathrm{A} 3$.

\section{Validation of the results}

Before making a decision, it is necessary to perform a validation of the obtained results. In this paper, the validation of the results is 
performed in three phases. In phase one, the initial rank of the alternatives gained by applying the BWM-COPRAS model is compared to the ranks obtained through the MIRCA (Chaterjee et al, 2018) and MABAC (Pamučar \& Ćirović, 2015) methods (Figure 3).

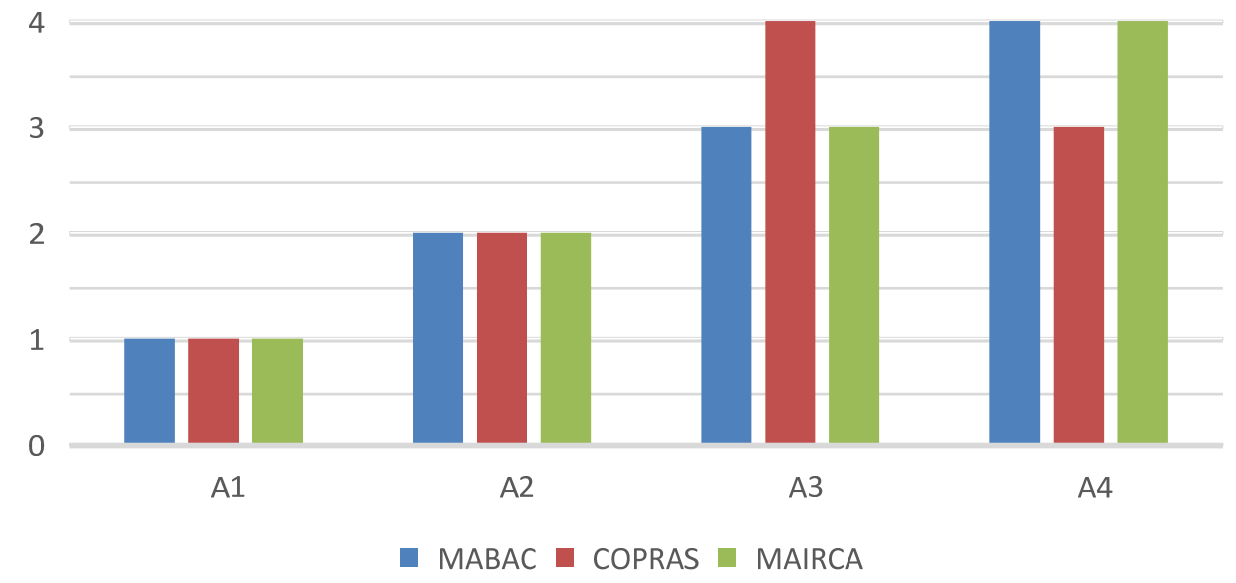

Figure 3 - Ranks of alternatives

Рис. 3 - Ранг альтернатив

Слика 3 - Ранг алтернатива

Compared to other methods, the rank of the alternatives $A 1$ and $A 2$ remained unchanged. The tesults obtained through the COPRAS method differ from those obtained through the MABAC and MAIRCA methods only in the position of the A3 and A4 alternatives. In order to determine the statistical significance between the ranks obtained through the BWMCOPRAS model and though other approaches, the Spearman's rank correlation coefficient was used (SRCC). The SRCC is the coefficient of the basic linear correlation between ranks. The Spearman's rank correlation coefficient is a non-parametrical method for ascertaining the strength of the correlation applied when (Pamučar et al, 2018b): (1) the data for at least one of the variables is displayed as ordinal data or in ranks, (2) at least one of the variables does not have a normal distribution, and (3) the ratio among variables is not linear. The value of the rank correlation coefficients is obtained through formula (11):

$$
R=1-\frac{6 \sum_{i=1}^{n} D_{a}^{2}}{n\left(n^{2}-1\right)} \in[-1,1]
$$


where $D$ represents the variance in the ranks and $n$ the number of the units of the analysis. The results of the rank comparison though the application of the SRCC are shown in Table 8.

Table 8 - Rank correlation of the tested methods Таблица 8 - Ранговая корреляция тестируемых методов Табела 8 - Корелација рангова тестираних метода

\begin{tabular}{llll}
\hline MCDM method & COPRAS & MAIRCA & MABAC \\
\hline SRCC & 0.800 & 1.000 & 1.000 \\
\hline
\end{tabular}

From Table 8, we see that the results of the MABAC and MAIRCA methods are in complete correlation, while the results of the COPRAS method have also shown a high level of correlation when compared to other methods. Since the lowest level of correlation is 0.8 and the middle value is 0.9 , we can conclude that the suggested rank is confirmed and credible.

The second phase of the result validation is a performance analysis of the proposed model in the dynamic basic matrix environment. In the dynamic basic matrix, for every scenario, a change in the number of alternatives was performed and the obtained ranks were analyzed. The matrices are formed by removing the lowest-ranking alternative, and then by ranking the remaining ones based on the newly-obtained basic decision-making matrix. By applying the BWM-COPRAS model, the solution $A 1>A 2>A 4>A 3$ was obtained. Given that the $A 3$ alternative is the worst in the modified matrix, $A 3$ is eliminated from the set of alternatives. The new decision-making matrix is solved again and we get a new rank $A 1>A 2>A 4$. After this, the worst alternative (A4) is once again eliminated, and with the application of the BWM-COPRAS model the final rank $A 1>A 2$ is obtained.

Based on the obtained results, we can conclude that, by eliminating the worst method, the rank of the remaining alternatives stays the same through all three scenarios. Alternative $A 1$ has stayed the best ranked through all scenarios which has confirmed the robustness of the ranks obtained in a dynamic environment.

The third phase of result validation is performed by changing the weight criteria. The goal of this phase of the result validation is to estimate the influence of the most influential criterion on the performances of ranking the proposed model. After determining the weight coefficients of the criteria by applying the BWM-COPRAS method for the purposes of sensitivity analysis, the "most important criterion" is 
identified. By applying formula (12), the weight proportionality is defined during the sensitivity analysis.

$w_{c}=\left(1-w_{s}\right) \times\left(w_{c}^{o} / W_{c}^{o}\right)=w_{c}^{o}-\Delta x \alpha_{c}$

where $w_{c}$ is the shift in the weight criteria within the sensitivity analysis, $w_{s}$ represents the weight of the most important criterion, $w_{c}^{o}$ represents the original values of the weight criteria and $W_{c}^{o}$ represents the sum of the original weight criteria values that are changing. The $\alpha_{c}$ parameter is defined as the weight coefficient of elasticity that expresses a relative compensation of other weight coefficient values compared to the given changes in the weight of the most important criterion. The $\alpha_{c}$ value is obtained through formula (13) (Kahraman, 2002).

$\alpha_{c}=w_{c}^{o} / W_{c}^{o}$

The assumptions during the performance of sensitivity analysis are as follows: (1) the value of the weight coefficient of elasticity for the most significant criterion is defined as one; (2) the ratio of the variable weights stays constant during the entirety of the sensitivity analysis (Kirkwood, 1997). The $\Delta x$ parameter (formula (12)) represents the amount of change applied to the set of weight coefficients depending on their weight coefficients of elasticity. The change of weights of the most important criteria should be limited. Otherwise, the weights can take on negative values which would lead to a disturbance in limiting the weight proportionality. The $\Delta x$ parameter can be (1) positive, which is indicated by the increase of the relative significance or (2) negative, as indicated by the decrease of the relative significance. The limits of $\Delta x$ are defined as the greatest change in weight of the most important criterion in the negative and positive direction. The boundary values of $\Delta x$ are defined by applying formula (14).

$-w_{s}^{o} \leq \Delta x \leq \min \left\{w_{c}^{o} / \alpha_{c}\right\}$

After defining the boundary values of $\Delta x$, new criteria weights are calculated according to the previously established parameters for the sensitivity analysis. The set of these new weight coefficient values is calculated using formulas (15) and (16).

$w_{s}=w_{s}^{o}+\alpha_{s} \Delta x$

$w_{c}=w_{c}^{o}-\alpha_{c} \Delta x$ 
where $w_{s}^{o}$ is the initial weight of the criteria subjected to the sensitivity analysis, $w_{c}^{o}$ je the original value of the variable weights. This new set of criteria always satisfies the universal state of weigh coefficient proportionality that $\sum w_{s}+\sum w_{c}=1$. Based on the newly-obtained criteria values, new ranks of alternatives for the given scenario are calculated.

In this research, the C5 criterion is identified as the most influential one because it has the highest weight coefficient value $w_{2}=0.276$. In the next step, the coefficient of weight elasticity of the most important criterion is determined $\left(\alpha_{s}\right)$ (Table 9 ) and the boundary values for the weight coefficient change of the most important criterion $(\Delta x)$ are defined.

Table 9 - Elasticity coefficient for changing weights

Таблица 9 - Коэфрфициент гибкости главных критериев

Табела 9 - Коефицијент еластичности најзначајнијед критеријума

\begin{tabular}{|c|c|c|}
\hline & Criteria labels & $\alpha_{s}$ \\
\hline C1 & & 0.1070 \\
\hline C2 & & 0.0820 \\
\hline C3 & & 0.0350 \\
\hline C4 & & 0.0110 \\
\hline C5 & & 1.0000 \\
\hline $\mathrm{C} 6$ & & 0.0480 \\
\hline $\mathrm{C7}$ & & 0.0747 \\
\hline C8 & & 0.2254 \\
\hline C9 & & 0.0747 \\
\hline C10 & & 0.1798 \\
\hline C11 & & 0.1632 \\
\hline
\end{tabular}

That is how the boundary values of the C5 criterion were obtained and they are $-0.2760 \leq \Delta x \leq 0.723$. Based on the defined boundaries of the weight coefficient change for the most important criterion, the scenarios for the sensitivity analysis were determined. The $-0.2760 \leq \Delta x \leq 0.723$ interval was divided into a total of 21 scenarios. After defining the boundary values of the most influential criterion, new weight coefficient values were defined for the 21 scenarios, Table 10.

The influence of the new weight coefficient values on the change of the ranks of alternatives is shown in Figure 4. 


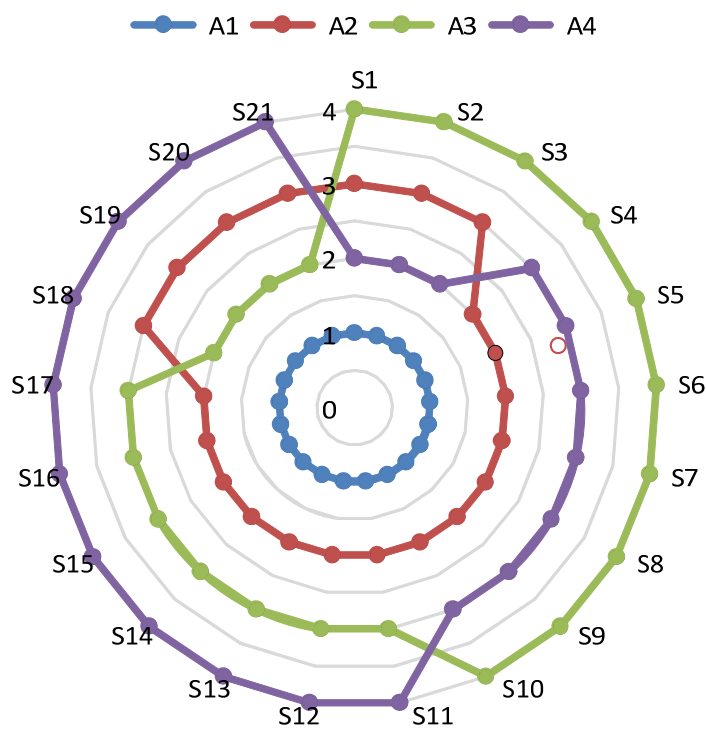

Figure 5 - Correlation coefficient for each scenario Pис. 5-Коэфффициент корреляции по каждому сценарию Слика 5-Коефицијент корелације за сценарије 


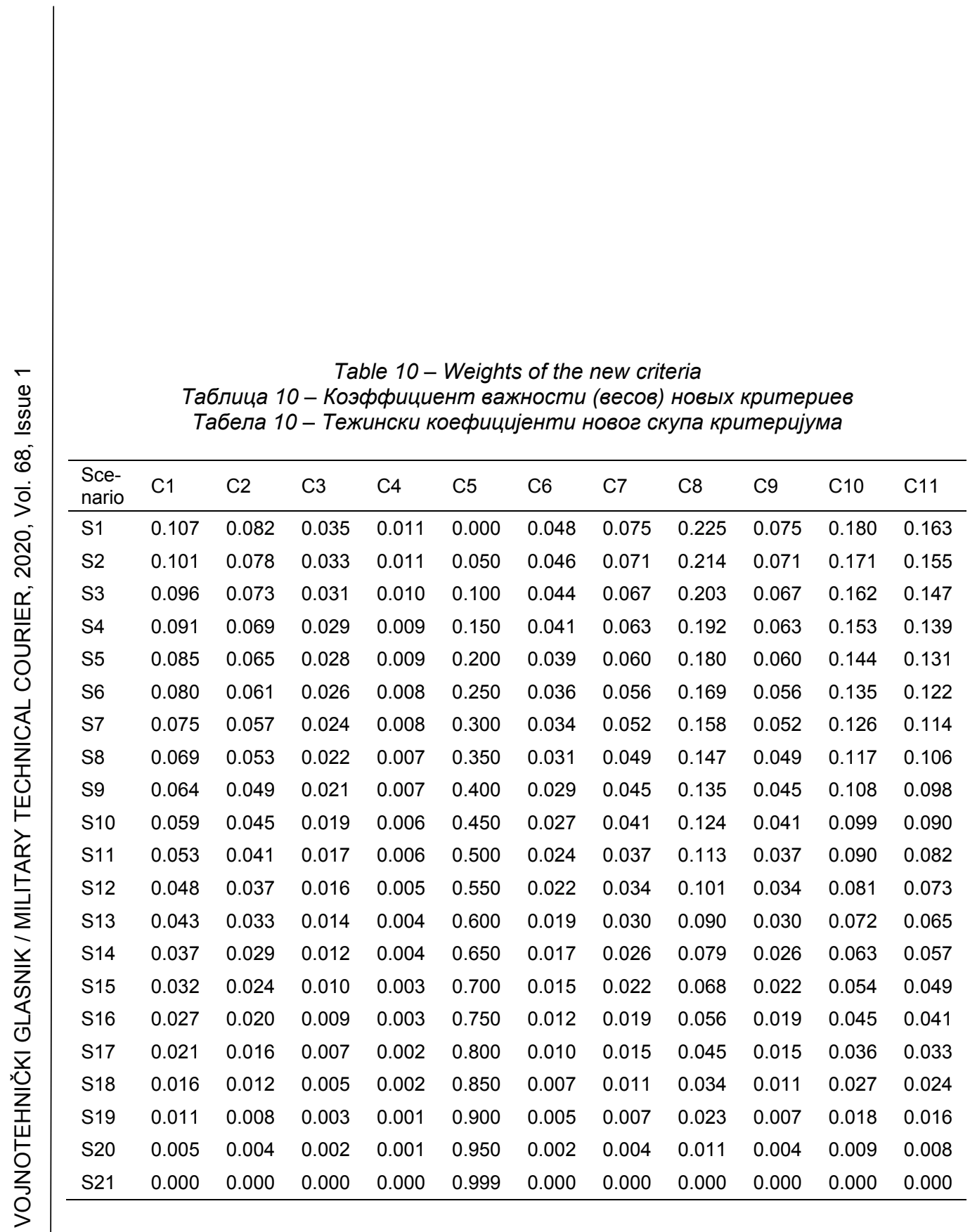

The medium value of the correlation coefficient for all scenarios is 0.752 - with this we conclude that the scenarios show a high degree of correlation. Given that $\mathrm{A} 1$ remained the highest ranked through all three phases of the result validation of alternatives, we can conclude that the proposed rank is confirmed and credible.

\section{Conclusion}

This research created the hybrid BWM-COPRAS model for the assessment of off-road vehicles for the units of the SAF. For the evaluation of alternatives, seven criteria used in the first hierarchical level were broken down into seven additional sub-criteria on the second hierarchical level. The key contribution of this paper is the new BWM- 
COPRAS model for the assessment of vehicles in the SAF, as well as the original BWM-MABAC and BWM-MAIRCA models which were created for the needs of result verification. The presented model enables the inclusion of subjectivities which arise in the process of group decision making through linguistic validation of evaluation criteria. In addition to this, though the model presented in this paper, new methodological bases for SAF vehicle evaluation were introduced, which simultaneously contributes to the betterment of the theoretical bases of multi-criteria decision making as a whole. The developed approach enables the bridging of the gap that currently exists within the methodology for offroad vehicle assessment for the units of the SAF. By choosing the optimal off-road vehicle, the risk of performing tasks for the SAF units is significantly lowered and their efficiency is greatly enhanced.

The hybrid BWM-COPRAS model has been applied for the assessment of the four vehicles considered for use in the SAF units. The obtained results were checked though the discussion of the results for different scenarios in which a dynamic environment was simulated through the application of weight criteria values. The stability of the model was verified through the statistical coefficient of correlation which showed a high correlation of the ranks in all scenarios. The research presented in this paper can serve as a methodology for decision making when choosing the optimal off-road vehicle. Also, the results can be used in the analysis of the certain criteria influence on the selection of the military vehicle, which can serve as a systematical approach to path defining in a model of the authority's decision making in the process of vehicle selection, in the military as well as in other complex systems.

\section{References}

Awasthi, A., \& Chauhan, S.S. 2011. Using AHP and Dempster-Shafer theory for evaluating sustainable transport solutions. Environmental Modelling and Software, 26(6), pp.787-796. Available at: https://doi.org/10.1016/j.envsoft.2010.11.010.

Awasthi, A., \& Chauhan, S.S. 2012. A hybrid approach integrating Affinity Diagram, AHP and fuzzy TOPSIS for sustainable city logistics planning. Applied Mathematical Modelling, 36(2), pp.573-584. Available at: https://doi.org/10.1016/j.apm.2011.07.033.

Awasthi, A., Chauhan, S.S., \& Omrani, H. 2011. Application of fuzzy TOPSIS in evaluating sustainable transportation systems. Expert Systems with Applications, 38(10), pp.12270-12280. Available at: https://doi.org/10.1016/j.eswa.2011.04.005. 
Badi, I.A., Abdulshahed, A.M., \& Shetwan, A.G. 2018. A Case Study Of Supplier Selection For A Steelmaking Company In Libya By Using The Combinative Distance-Based Assessment (Codas) Model. Decision Making: Applications in Management and Engineering, 1(1), pp.1-12. Available at: https://doi.org/10.31181/dmame180101b.

Badi, I., \& Ballem, M. 2018. Supplier Selection using Rough BWM-MAIRCA model: A case study in Pharmaceutical Supplying in Libya. Decision Making: Applications in Management and Engineering, 1(2) [online]. Available at: https://www.dmame.org/index.php/dmame/article/view/12/11. [Accessed: 21 August 2019]

Barić, D., Pilko, H., \& Strujić, J. 2016. An Analytic Hierarchy Process Model To Evaluate Road Section Design. Transport, 31(3), pp.312-321. Available at: https://doi.org/10.3846/16484142.2016.1157830.

Bojković, N., Anić, I., \& Pejčić-Tarle, S. 2010. One solution for crosscountry transport-sustainability evaluation using a modified ELECTRE method. Ecological Economics, 69(5), pp.1176-1186. Available at: https://doi.org/10.1016/j.ecolecon.2010.01.006.

Cadena, P.C.B., \& Magro, J.M.V. 2015. Setting The Weights Of Sustainability Criteria For The Appraisal Of Transport Projects. Transport, 30(3), pp.298-306. Available at: https://doi.org/10.3846/16484142.2015.1086890.

Castillo, H., \& Pitfield, D.E. 2010. ELASTIC - A methodological framework for identifying and selecting sustainable transport indicators. Transportation Research Part D: Transport and Environment, 15(4), pp.179-188. Available at: https://doi.org/10.1016/j.trd.2009.09.002

Chatterjee, K., Pamucar, D., \& Zavadskas, E.K. 2018. Evaluating the performance of suppliers based on using the R'AMATEL-MAIRCA method for green supply chain implementation in electronics industry. Journal of Cleaner Production, 184, pp.101-129. Available at: https://doi.org/10.1016/j.jclepro.2018.02.186.

Dimić, S., Pamučar, D., Ljubojević, S., \& Đorović, B. 2016. Strategic Transport Management Models-The Case Study of an Oil Industry. Sustainability, 8(9), p.954. Available at: https://doi.org/10.3390/su8090954.

Fazlollahtabar, H. 2018. Operations and inspection Cost minimization for a reverse supply chain, Operational Research in Engineering Sciences: Theory and Applications, 1(1), pp.91-107 [online]. Available at: http://www.oresta.org/index.php/oresta/article/view/8/8. [Accessed: 21 August 2019]

Fazlollahtabar, H., Smailbašić, A., \& Stević, Ž. 2019. FUCOM method in group decision-making: Selection of forklift in a warehouse. Decision Making: Applications in Management and Engineering, 2(1), pp.49-65 [online]. Available at: https://www.dmame.org/index.php/dmame/article/view/26/24. [Accessed: 21 August 2019]

Inti, S., \& Tandon, V. 2017. Application of Fuzzy Preference-Analytic Hierarchy Process Logic in Evaluating Sustainability of Transportation Infrastructure Requiring Multicriteria Decision Making. Journal of Infrastructure Systems, 23(4), p.4017014. Available at: https://doi.org/10.1061/(asce)is.1943-555x.0000373. 
Jeon, C.M., Amekudzi, A.A., \& Guensler, R.L. 2010. Evaluating Plan Alternatives for Transportation System Sustainability: Atlanta Metropolitan Region. International Journal of Sustainable Transportation, 4(4), pp.227-247.

Jiang, P., Hu, Y., Yen, G., Jiang, H., \& Chiu, Y. 2018. Using a Novel Grey DANP Model to Identify Interactions between Manufacturing and Logistics Industries in China. Sustainability, 10(10), p.3456. Available at: https://doi.org/10.3390/su10103456.

Jones, S., Tefe, M., \& Appiah-Opoku, S. 2013. Proposed framework for sustainability screening of urban transport projects in developing countries: A case study of Accra, Ghana. Transportation Research Part A: Policy and Practice, 49, pp.21-34. Available at: https://doi.org/10.1016/j.tra.2013.01.003.

Kahraman, Y.R. 2002. Robust sensitivity analysis for multi-attribute deterministic hierarchical value models. Ohio: Storming Media.

Kirkwood, C.W. 1997. Strategic decision making: Multi-objective decision analysis with Spreadsheets. Belmont: Duxbury Press.

López, E., \& Monzón, A. 2010. Integration of Sustainability Issues in Strategic Transportation Planning: A Multi-criteria Model for the Assessment of Transport Infrastructure Plans. Computer-Aided Civil and Infrastructure Engineering, 25(6), pp.440-451. Available at: https://doi.org/10.1111/j.14678667.2010.00652.x.

Mavi, R.K., Goh, M., \& Zarbakhshnia, N. 2017. Sustainable third-party reverse logistic provider selection with fuzzy SWARA and fuzzy MOORA in plastic industry. The International Journal of Advanced Manufacturing Technology, 91(5-8), pp.2401-2418. Available at: https://doi.org/10.1007/s00170-016-9880-x.

Mitropoulos, L.K., \& Prevedouros, P.D. 2016. Incorporating sustainability assessment in transportation planning: an urban transportation vehicle-based approach. Transportation Planning and Technology, 39(5), pp.439-463. Available at: https://doi.org/10.1080/03081060.2016.1174363.

Mukhametzyanov, I., \& Pamučar, D. 2018. A Sensitivity analysis in MCDM problems: A statistical approach. Decision Making: Applications in Management and Engineering, 1(2) [online]. Available at: https://www.dmame.org/index.php/dmame/article/view/14/14. [Accessed: 21 August 2019]

Noureddine, M., \& Ristic, M. 2019. Route planning for hazardous materials transportation: Multicriteria decision making approach. Decision Making: Applications in Management and Engineering, 2(1), pp.66-85 [online]. Availabele at: https://www.dmame.org/index.php/dmame/article/view/29/25. [Accessed: 21 August 2019]

Nunić, Z. 2018. Evaluation and selection of the PVC carpentry Manufacturer using the FUCOM-MABAC model. Operational Research in Engineering Sciences: Theory and Applications, 1(1), pp.13-28 [online]. Available at: https://www.oresta.org/index.php/oresta/article/view/3/3. [Accessed: 21 August 2019] 
Pamučar, D., Badi, I., Sanja, K., \& Obradović, R. 2018a. A Novel Approach for the Selection of Power-Generation Technology Using a Linguistic Neutrosophic CODAS Method: A Case Study in Libya. Energies, 11(9), p.2489. Available at: https://doi.org/10.3390/en11092489.

Pamučar, D., \& Ćirović, G. 2015. The selection of transport and handling resources in logistics centers using Multi-Attributive Border Approximation area Comparison (MABAC). Expert Systems with Applications, 42(6), pp.3016-3028. Available at: https://doi.org/10.1016/j.eswa.2014.11.057.

Pamučar, D., Lukovac, V., Božanić, D., Komazec, N. 2018b. Multi-criteria FUCOM-MAIRCA model for the evaluation of level crossings: case study in the Republic of Serbia. Operational Research in Engineering Sciences: Theory and Applications, 1(1), pp.108-129 [online]. Available at: http://www.oresta.org/index.php/oresta/article/view/10/9. [Accessed: 21 August 2019]

Pamučar, D., Lukovac, V., \& Pejčić-Tarle, S. 2013. Application Of Adaptive Neuro Fuzzy Inference System In The Process Of Transportation Support. AsiaPacific Journal of Operational Research, 30(02), p.1250053. Available at: https://doi.org/10.1142/s0217595912500534.

Pamučar, D., Sremac, S., Stević, Ž., Ćirović, G., \& Tomić, D. 2019. New multi-criteria LNN WASPAS model for evaluating the work of advisors in the transport of hazardous goods. Neural Computing and Applications, 31(9), pp.5045-5068. Available at: https://doi.org/10.1007/s00521-018-03997-7

Pamucar, D.S., Tarle, S.P., \& Parezanovic, T. 2018a. New hybrid multicriteria decision-making DEMATEL-MAIRCA model: Sustainable selection of a location for the development of multimodal logistics centre. Economic Research/Ekonomska Istraživanja, 31(1), pp.1641-1665.

Pamučar, D., Vasin, L., Atanasković, P., \& Miličić, M. 2016. Planning the City Logistics Terminal Location by Applying the Green $p$-Median Model and Type-2 Neurofuzzy Network. Computational Intelligence and Neuroscience, , pp.1-15. Available at: https://doi.org/10.1155/2016/6972818.

Puška, A., Maksimović, A., Stojanović, I. 2018. Improving organizational learning by sharing information through innovative supply chain in agro-food companies from Bosnia and Herzegovina. Operational Research in Engineering Sciences: Theory and Applications, 1(1), pp.76-90 [online]. Available at: http://www.oresta.org/index.php/oresta/article/view/7/7. [Accessed: 21 August 2019]

Radović, D., Stević, Ž., Pamučar, D., Zavadskas, E., Badi, I., Antuchevičiene, J., \& Turskis, Z. 2018. Measuring Performance in Transportation Companies in Developing Countries: A Novel Rough ARAS Model. Symmetry, 10(10), p.434. Available at: https://doi.org/10.3390/sym10100434.

Rao, C., Goh, M., Zhao, Y., \& Zheng, J. 2015. Location selection of city logistics centers under sustainability. Transportation Research Part D: Transport and Environment, 36, pp.29-44. Available at: https://doi.org/10.1016/j.trd.2015.02.008. 
Rezaei, J. 2015. Best-worst multi-criteria decision-making method. Omega, 53(June), pp.49-57. Available at: https://doi.org/10.1016/j.omega.2014.11.009.

Safaei Mohamadabadi, H.S., Tichkowsky, G., \& Kumar, A. 2009. Development of a multi-criteria assessment model for ranking of renewable and non-renewable transportation fuel vehicles. Energy, 34(1), pp.112-125. Available at: https://doi.org/10.1016/j.energy.2008.09.004.

Simongáti, G. 2010. Multi-Criteria Decision Making Support Tool For Freight Integrators: Selecting The Most Sustainable Alternative. Transport, 25(1), pp.89-97. Available at: https://doi.org/10.3846/transport.2010.12.

Sremac, S., Stević, Ž., Pamučar, D., Arsić, M., \& Matić, B. 2018. Evaluation of a Third-Party Logistics (3PL) Provider Using a Rough SWARA-WASPAS Model Based on a New Rough Dombi Agregator. Symmetry, 10(8), p.305. Available at: https://doi.org/10.3390/sym10080305.

Stanković, M., Gladović, P., \& Popović, V. 2019. Determining the importance of the criteria of traffic accessibility using fuzzy AHP and rough AHP method. Decision Making: Applications in Management and Engineering, 2(1), pp.86-104 [online]. Available at: https://www.dmame.org/index.php/dmame/article/view/27/26. [Accessed: 21 August 2019]

Stanujkić, D., \& Karabašević, D. 2018. An extension of the WASPAS method for decision-making problems with intuitionistic fuzzy numbers: a case of website evaluation. Operational Research in Engineering Sciences: Theory and Applications, 1(1), pp.29-39 [online]. Available at: http://www.oresta.org/index.php/oresta/article/view/4/4. [Accessed: 21 August 2019]

Starcevic, S., Bojovic, N., Skrickij, V., \& Junevičius, R. 2019. AHP method and data envelopment analysis application in terrain vehicle selection for the purposes of military units engagement in multinational operations. Transport, in press.

Stević, Ž., Pamučar, D., Kazimieras, Z.E., Ćirović, G., \& Prentkovskis, O. 2017. The Selection of Wagons for the Internal Transport of a Logistics Company: A Novel Approach Based on Rough BWM and Rough SAW Methods. Symmetry, 9(11), p.264. Available at: https://doi.org/10.3390/sym9110264.

Stević, Ž., Pamučar, D., Subotić, M., Antuchevičiene, J., \& Zavadskas, E.K. 2018. The Location Selection for Roundabout Construction Using Rough BWMRough WASPAS Approach Based on a New Rough Hamy Aggregator. Sustainability, 10(8), p.2817. Available at: https://doi.org/10.3390/su10082817.

Turskis, Z., \& Zavadskas, E.K. 2010. A New Fuzzy Additive Ratio Assessment Method (Aras-F). Case Study: The Analysis Of Fuzzy Multiple Criteria In Order To Select The Logistic Centers Location. Transport, 25(4), pp.423-432. Available at: https://doi.org/10.3846/transport.2010.52.

Wang, H., Jiang, Z., Zhang, H., Wang, Y., Yang, Y., \& Li, Y. 2018. An integrated MCDM approach considering demands-matching for reverse logistics. Journal of Cleaner Production, 208, pp.199-210. Available at: https://doi.org/10.1016/j.jclepro.2018.10.131. 
Zavadskas, E.K., \& Kaklauskas, A. 1996. Multiple Criteria Evaluation of Buildings. Vilnius: Technika (in Lithuanian).

Zečević, S., Tadić, S., \& Krstić, M. 2017. Intermodal Transport Terminal Location Selection Using a Novel Hybrid MCDM Model. International Journal of Uncertainty, Fuzziness and Knowledge-Based Systems, 25(06), pp.853-876. Available at: https://doi.org/10.1142/s0218488517500362.

\section{МНОГОКРИТЕРИАЛЬНАЯ МОДЕЛЬ ВЫБОРА ОПТИМАЛЬНОГО ВНЕДОРОЖНОГО ТРАНСПОРТНОГО СРЕДСТВА ДЛЯ ОСУЩЕСТВЛЕНИЯ ПЕРЕВОЗКИ ПАССАЖИРОВ: ВWM-COPRАS МОДЕЛЬ}

Драган С. Памучар, корреспондент, Лазар М. Савин

Университет обороны в г. Белград, Военная академия, Департамент логистики, г. Белград, Республика Сербия

РУБРИКА ГРНТИ: 28.17.31 Моделирование процессов управления ВИД СТАТЬИ: оригинальная научная статья ЯЗЫК СТАТЬИ: английский

Резюме:

Введение/цель: Соответствующее развитие и выбор внедорожных транспортных средств с целью выполнения различных видов задач являются весьма важными фракторами, которые влияют на мобильность пользователей, качество передвижения и безопасность при выполнении транспортной деятельности в рамках Вооруженных сил Республики Сербия (BCPC), а также на эфрфективность ее осуществления.

Методы: В данной работе представлена модель для выбора оптимального внедорожного транспортного средства для нужд BCPC, с применением BWM (Best Worst Method) u COPRAS (Compressed Proportional Assessment) моделей. Определение относительной сложности критериев на основании, которых производится оценка потенциальных внедорожных транспортных средств выполнено с помощью BWM метода. Наряду с COPRAS методом, который является неотъемлемой частью основной модели принятия решений, в данной работе в части валидации результатов применялись и MABAC (MultiAttributive Border Approximation area Comparison) u MAIRCA (MultiAtributive Ideal-Real Comparative Analysis) методы.

Результаты: Испытание BWM-COPRAS модели проведено на примере выбора оптимального внедорожного транспортного средства в ВСС в результате чего был получен высокий коэфорициент корреляции рангов. Валидация результатов выполнена с помощью статистической обработки данных, полученных благодаря применению различных 
многокритериальных методов, в том числе коэффрициента корреляций рангов Спирмена.

Выводы: Полученные результаты показывают устойчивость результатов предлагаемой модели при ранжировании альтернатив и доказывают ее применимость для решений многокритериальных задач.

Ключевые слова: BWM, COPRAS, MABAC, MAIRCA, выбор автомобиля, принятие многокритериальных решений.

ВИШЕКРИТЕРИЈУМСКИ ВWМ-СОРRАS МОДЕЛ ЗА ИЗБОР ОПТИМАЛНОГ ТЕРЕНСКОГ ВОЗИЛА ЗА ПРЕВОЗ ПУТНИКА

Драган С. Памучар, аутор за преписку, Лазар М. Савин

Универзитет одбране у Београду, Војна академија,

Катедра логистике, Београд, Република Србија

ОБЛАСТ: математика, саобраћај, логистика

ВРСТА ЧЛАНКА: оригинални научни рад

JЕЗИК ЧЛАНКА: енглески

\section{Сажетак:}

Увод/циљ: Адекватна евалуација и избор теренског возила за извршење различитих врста задатака веома је важан фактор који утиче на мобилност корисника, њихову безбедност, као и на квалитет и ефикасност извршавања транспортних активности у Војсци Србије (BC).

Memode: Cтога је за избор оптималног теренског возила за потребе BC, у овом раду предложен BWM (Best Worst Method) u COPRAS (Compressed Proportional Assessment) модел . Одређивање релативних тежина критеријума, на основу којих се врши вредновање потенцијалних теренских возила, извршено је применом BWM методе. Поред COPRAS методе, која је саставни део основног модела за доношење одлуке, у овом раду су, кроз валидацију резултата, примењене и методе MABAC (MultiAttributive Border Approximation area Comparison) u MAIRCA (MultiAtributive IdealReal Comparative Analysis).

Резултати: Тестирањем BWM-COPRAS модела на примеру избора оптималног теренског возила у ВC добијена је висока корелација рангова. Валидација резултата извршена је статистичком обрадом резултата добијених различитим вишекритеријумским техникама, применом Спирмановог коефицијента корелације.

Закључак: Резултати показују стабилност резултата предложеног модела у рангирању алтернатива и доказују његову примењивост за решавање вишекритеријумских проблема.

Кључне речи: BWM, COPRAS, MABAC, MAIRCA, избор возила, доношење вишекритеријумских одлука. 
Paper received on / Дата получения работы / Датум пријема чланка: 23.08.2019. Manuscript corrections submitted on / Дата получения исправленной версии работы / Датум достављања исправки рукописа: 14.12.2019.

Paper accepted for publishing on / Дата окончательного согласования работы / Датум коначног прихватања чланка за објављивање: 16.12.2019.

(c) 2020 The Authors. Published by Vojnotehnički glasnik / Military Technical Courier

(www.vtg.mod.gov.rs, втг.мо.упр.срб). This article is an open access article distributed under the terms and conditions of the Creative Commons Attribution license (http://creativecommons.org/licenses/by/3.0/rs/).

() 2020 Авторы. Опубликовано в «Военно-технический вестник / Vojnotehnički glasnik / Military Technical Courier» (www.vtg.mod.gov.rs, втг.мо.упр.срб). Данная статья в открытом доступе и распространяется в соответствии с лицензией «Creative Commons» (http://creativecommons.org/licenses/by/3.0/rs/).

( 2020 Аутори. Објавио Војнотехнички гласник / Vojnotehnički glasnik / Military Technical Courier (www.vtg.mod.gov.rs, втг.мо.упр.срб). Ово је чланак отвореног приступа и дистрибуира се у складу са Creative Commons licencom (http://creativecommons.org/licenses/by/3.0/rs/).

(c) (i) 